\title{
UMA ANÁLISE DE HISTÓRIA DAS RELAÇõES INTERNACIONAIS: AS ESTRATÉGIAS ADOTADAS PELA SANTA SÉ NA SEGUNDA GUERRA MUNDIAL
}

Paula Antonia Henn ${ }^{1}$

Marta Rosa Borin²

\section{Resumo}

A história das relações internacionais tem assumido um lugar de importância na Nova História Política e nos atuais debates da disciplina. Juntamente com isso, um ator das relações internacionais que possui uma posição ímpar no cenário mundial é a Santa Sé, o instrumento responsável pelos assuntos políticos e temporais da Igreja Católica. Com o Tratado de Latrão firmado entre o Estado italiano e o Vaticano em 1929 a Igreja Católica passou a ser detentora de um território nacional condição esta que firmou sua situação de sujeito de direito internacional. Possuindo pouco território, a Igreja Católica influencia os católicos espalhados pelo mundo o que faz de seu representante um forte líder político que além de assegurar a expansão do credo, envolve-se no cenário internacional.O objetivo deste artigo é fazer uma breve análise sobre a história das relações internacionais da Santa Sé durante a Segunda Guerra Mundial, período esse em que o Pontífice Romano era o Papa Pio XII (Cardeal Pacelli). Aprofundar a essência diplomática desta instituição durante o Pontificado de Pio XII e traçar linhas de análise crítica de suas ações e conceitos políticos.

Palavras-chave: História das Relações Internacionais. Santa Sé. Segunda Guerra Mundial.

\begin{abstract}
The international relations' history has assumed a site of importance in New Politic History and in the actual course's debates. Together with it, an international relations' actor that possess a unique position in world scenario is Holy See, the instrument

\footnotetext{
1 Mestranda no Programa Pós Graduação em História da UFSM. Departamento de História, Centro de Ciências Sociais e Humanas. Graduada em Relações Internacionais pela UFSM. Bolsista Capes. E-mail: paulahenn@hotmail.com

2 Doutora em História. Professora do Programa de Pós Graduação em História na Universidade Federal de Santa
} Maria. E-mail: mrborin@gmail.com
\end{abstract}


responsible for politic and temporal matters of Catholic Church. With Lateran Treaty signed between Italian State and Vatican in 1929, Catholic Church became owner of a national territory, establishing its situation of international high subject. Having a little territory, Catholic Church influences more than 1 billion of Catholics all over the world, what makes its representative a significant political leader that in addition to assure the expansion of creed, get involved in international scenario. The objective of this paper is to make a short analysis about international relations' history of Holy See during Second World War, period during which Roman Pontiff was Pope Pius XII (Cardinal Pacelli). Deeping diplomatic essence of this institution during Pius XII's Pontificate and draw lines of critical analysis of his actions and political concepts.

Keywords: Internacional Relations History. Holy See. Second World War.

\section{INTRODUÇÃO}

A história das relações internacionais tem assumido um lugar de maior destaque na nova historiografia política, seja pela necessidade em analisar os processos históricos internacionais ou pelo anseio de uma compreensão mais ampla e interligada nos diversos meios de interação com o exterior. Lançar o olhar sobre os movimentos exteriores torna as análises históricas mais ricas e abrangentes.

A nova historiografia política enfatiza a importância das ações individuais ou de grupos, diferente da antiga interpretação que se apresentava de modo um tanto determinista que considerava que a liberdade de escolha do indivíduo estava subordinada a das forças sociais, sendo as que de fato determinariam os grandes acontecimentos (MONTENEGRO et. al. 2013). François Dosse (1994) faz uma afirmação que toca essa realidade, segundo ele o político fecunda de novo o campo histórico, dessa forma dando-lhe dinamismo e um novo ânimo.

Essa nova História Política é, primordialmente, diferente dos padrões tradicionais da antiga História Política, como argumenta René Rémond (1999, p. 
53-58): " ao estudar o fenômeno político, o historiador deve estar atento às relações que se estabelecem entre o indivíduo e a "sociedade global política", com o estudo de comportamentos, escolhas, convicções, lembranças, memória, cultura, pois "o político toca a muitas coisas". O autor reconhece que, embora história política e história recente sejam abordagens diferentes, os mesmos historiadores militaram e militam pelas duas causas.

A história diplomática não escapou do descrédito que inferiram os pressupostos metodológicos da Escola dos Annales $^{3}$ a todo trabalho histórico realizado mediante o emprego da metodologia positivista. Além disso, as relações internacionais passaram a assumir a influência das chamadas forças profundas, ponto de referência fundamental nas obras de P. Renouvin e J. B. Duroselle ( $1967 ; 1994 ; 2002)$, que partindo dos princípios enunciados pela Escola dos Annales, propunham a nova metodologia que orientou as investigações e reflexões em torno das relações internacionais: a compreensão da ação diplomática através da análise das condições geográficas, as correntes sentimentais, os rasgos da mentalidade coletiva e os indivíduos, especialmente os homens de Estado, já que são estes através do exercício de seus cargos, os que decidiram e projetaram a estrutura das relações internacionais (MONTENEGRO, op.cit.).

Assim sendo, aos olhos das Relações Internacionais, não é possível analisar a Santa Sé como um simples instrumento religioso. Sendo intervenientes mais antigos do cenário internacional, a sua teia de ligações e o seu legado à Europa e ao Mundo ultrapassam a esfera religiosa, abrangendo a política, a sociedade, a cultura e, sobretudo, limitando o Homem de acordo com

\footnotetext{
3 Surgiu em 1929 na França uma revista intitulada Annales d'Histoire Économique et Sociale, fundada por Lucien Febvre e Marc Bloch. A proposta inicial do periódico era se livrar de uma visão positivista da escrita da História que havia dominado o final do século XIX e início do XX. Foi responsável por introduzir uma nova perspectiva para 0 estudo da História ao considerá-la não mais apenas como uma sequência de acontecimentos. A Escola dos Annales foi responsável pela promoção da interdisciplinaridade que aproximou a História das demais Ciências Sociais e foram incorporados os domínios dos fatores econômicos, da organização social e da psicologia das mentalidades.
} 
os desígnios do Evangelho, desígnios esses que a Igreja Católica delineou como a vontade divina que define a conduta moral dos Homens.

Assim, nos balizaremos em Martins (2011) quando adverte que a análise histórica que se constrói no campo das relações internacionais busca reconstituir os contextos políticos, sociais, econômicos e culturais que estão intrínsecas nos acontecimentos políticos internos e externos, estatais ou não.

É perante este quadro amplo e complexo que se construirá este estudo. Como a diplomacia da Santa Sé tem seu representante principal o Pontífice de Roma, que orienta as posições internacionais dos representantes do Vaticano, nossa proposta da pesquisa visa analisar as posturas político-diplomáticas, através da história das relações internacionais durante o Pontificado de Pio XII no período de 1939 a 1945. Neste período, as nações europeias viviam a instabilidade das frágeis democracias e, também, passaram pelo conflito da Segunda Guerra Mundial que modificou o cenário internacional e exigiu uma posição de todas as nações frente ao conflito.

Assim, busca-se identificar e analisar, através da história das relações internacionais, as estratégias política do referido pontífice em relação ao nacional-socialismo, as possíveis razões que motivaram suas ações ou silêncios diante da política internacional daquele período.

\section{ESTADO NAÇÃO E A DIPLOMACIA DA SANTA SÉ}

A Santa Sé é quem age internacionalmente e diplomaticamente nas relações internacionais do Vaticano e não propriamente o Estado da Cidade do Vaticano, sendo que a mesma é autoridade suprema da Igreja Católica. Como 
uma instituição confessional, a Igreja Católica é a única a ter um Estado e possuir reconhecimento internacional de sua soberania.

As relações entre os Estados e a Santa Sé são assim, como entre qualquer Estado do globo, relação entre sujeitos de direito internacional. A grande diferença está no que tange ao conteúdo das relações não são questões militares, comerciais e financeiras ou, até mesmo, alianças políticas, mas sim as questões geralmente tratadas diplomaticamente dizem respeito à Igreja Católica.

A Santa Sé diante dos outros Estados se apresenta como autoridade suprema da Igreja Católica, não como representante soberano do próprio Estado na comunidade internacional.( SOUZA,2008) Neste sentido, a Igreja passa a ser uma organização universal presente no mundo inteiro. A atuação internacional fundamenta-se na autoridade moral, soberana e independente que, atualmente lhe é reconhecida por quase todos os países sua (CARLETTI, 2012). A relativa facilidade nas suas relações diplomáticas se dá em grande parte pelo número de membros espalhados pelo mundo ultrapassando1 bilhão de fiéis.

Atualmente, a Santa Sé age no âmbito internacional por meio da diplomacia bilateral e multilateral. Ela se apresenta ao mundo essencialmente como uma autoridade espiritual e moral. Segundo Moreira (1996, p. 122), “a nova definição internacional da Santa Sé, que assume um protagonismo específico na vida internacional, vai basear-se, não em qualquer poder político, mas sim e apenas na autoridade, isto é, uma proeminência institucional reconhecida que permite influenciar as condutas e as decisões".

Há uma divisão relevante na organização da Igreja Católica, diferenciando o Vaticano da Santa Sé, mas os dois têm papéis distintos em nível político e religioso. O Vaticano representa de alguma maneira o amparo da atividade da Santa Sé, dotada essa de uma soberania reconhecida 
internacionalmente, antes mesmo da constituição do Estado da Cidade do Vaticano, em 1929. A Santa Sé era reconhecida como sujeito internacional já na formação dos primeiros estados absolutistas e após a Paz de Westfália, em 1648 (PORTILHO,2011). Nessa época, mesmo com seu poder temporal enfraquecido, os pontífices não deixavam de influenciar na política internacional. O Estado da Cidade do Vaticano encontrava-se em uma posição, de certa forma, subordinada a Santa Sé (CARLETTI, 2012). Os Tratados de Latrão dotaram a Santa Sé de um apoio territorial suficiente para garantir sua autonomia internacional. Graças a essa autonomia, o papa, livre da influência de qualquer outro Estado, pode exercer suas funções de Chefe da Igreja Católica. (LEBEC, 1999, p. 7). Mas, é um Estado soberano que mesmo apresentando os elementos típicos dos outros estados, possui funções e interesses diferentes.

A Santa Sé em especial atua em âmbito internacional assumindo uma posição de ordem, zelando pela harmonia entre os poderes juntamente com a possibilidade que abrange de ampliar o seu discurso internacionalmente. Dessa forma pode-se dizer que assume um posicionamento de soft power, fazendo-se presente nas transformações e realidades no mundo atualmente. Não existe uma unanimidade sobre a Santa Sé desempenhar o soft power no cenário internacional como afirma Reis (2007):

Uma faceta importante do peculiar poder papal é, portanto, captada pela noção de poder suave ( soft power ) popularizada por Joseph Nye, o qual apresenta o Vaticano como um exemplo paradigmático da relevância desse seu conceito. Pois sem dúvida que o papa exerce um poder de atração - afinal a adesão ao catolicismo é voluntária. Parece-nos, no entanto, que o poder da Santa Sé não pode ser reduzido a este aspecto. Seria um erro ignorar que o papa exerce uma autoridade normativa - ética e religiosa - muito importante. Mas seria igualmente um erro esquecer que detém um poder institucional bem duro. A permanência na Igreja pode ser atualmente voluntária, mas a organização hierárquica do catolicismo, centrada no papa, não o é. O caráter peculiar desta combinação entre igreja e Estado, jogando em dois tabuleiros ao mesmo tempo - com o prestígio 
e poder normativo de um líder religioso e com a imunidade e a capacidade de ação independente de um líder estatal - pode ser traduzida em termos do Vaticano como um Estado de poder suave, e do catolicismo como uma igreja de poder duro.

Desta maneira sendo a Santa Sé portadora de personalidade jurídica, deve atuar não só como propagadora da fé como agir no cenário da política internacional usando das ferramentas de que dispões. As correntes de pensamento das relações internacionais sempre estiveram intrínsecas nas ações da política externa do Vaticano.

Como afirma Salmo de Souza (2008) há um sentido amplo e geral em que a Santa Sé depreende não só o Pontífice Romano mas também a Secretaria de Estado, mas no sentido estrito e especial o termo Santa Sé se refere somente ao Romano Pontífice à sua função e ao Papado. Por esse motivo nos deteremos ao sentido estrito de análise da Santa Sé para compreender as atitudes e posições tomadas pelo Papa Pio XII durante o conflito mundial que se desenrolou em seu pontificado.

\section{DE CARDEAL PACELLI A PAPA PIO XII}

Eugênio Pacelli nasceu em 1876, em Roma, de família católica e com tradição nos trabalhos pontifícios, sendo distinguida pelos serviços prestados a Santa Sé. Pacelli foi ordenado sacerdote em 1899, com 23 anos de idade. Depois de dois anos em trabalhos paroquiais foi chamado a ingressar na Congregação dos Assuntos Eclesiásticos Extraordinários da Santa Sé, sendo responsável pelas relações internacionais (TORNIELLLI, 2002). 
Passados vinte e um anos, em 1920, Pacelli foi nomeado Núncio Apostólico $^{4}$ na nova República Federal da Alemanha, assumindo o cargo no período entre guerras, até a conclusão dos acordos com a Baviera (1924) e com a Prússia (1929). Foi instituído Cardeal5', em 1929, pelo Papa Pio XI, retornando à Roma no ano seguinte para assumir a nomeação de Secretário de Estado. A partir desse cargo, Eugênio Pacelli passou a representar o Papa em viagens, encontros e negociações políticas. Durante este período assumiu uma posição de muita importância, Carletti (2012) afirma que seu serviço era de vice Papa, e desta maneira tornou-se conhecido em todo mundo, e conhecedor do ambiente diplomático.

Para Lebec (1999), o profundo conhecimento da língua alemã fez de Pacelli um importante sujeito nas negociações políticas como a assinatura da Concordata da Santa Sé com a Alemanha, em 1933, a qual estabelecia pontos bem claros sobre as relações entre a Alemanha de Hitler e a Santa Sé. Segundo Godman (2007), a primeira condição era que a Alemanha não declarasse guerra a Santa Sé ou à hierarquia da Igreja na Alemanha, em contrapartida a Santa Sé cumpriria com alguns acordos como: não condenar o partido de Hitler, permitir que os católicos fossem membros do Partido Fascista e do partido Nazista (Partido Nacional Socialista dos Trabalhadores Alemães) liderado por Adolf Hitler, desde1921. Tal concordata foi essencial para a vitória nas eleições dos nazistas e seus aliados no Reich, já que depois deste acordo os bispos alemães suspenderam as condenações que faziam ao Partido (PORTILHO, 2011).

Durante todo o pontificado de Pio XI (1922-1939), o cardeal Pacelli, muito próximo ao papa, assumiu o papel de secretário de Estado e também todas as funções referentes a um vice governo, o que influenciou em sua posterior

${ }^{4} 0$ núncio apostólico é o representante diplomático permanente da Santa Sé, não do Estado da Cidade do Vaticano, exerce 0 posto de embaixador. Representa a Santa Sé perante os Estados, perante algumas organizações internacionais e perante a igreja local.

${ }^{5} \mathrm{Na}$ hierarquia da igreja, os cardeais são os conselheiros e os colaboradores mais íntimos do Papa. 
91 InterAção

eleição para substituir Pio XI na função (GRIGULÉVICH: 1982, p.144). O Cardeal Pacelli foi escolhido para assumir o cargo mais alto da Igreja Católica no dia 1 de março de 1939, adotando o nome de Pio XII como uma menção à continuidade do papado precedente, o de Pio XI. Sendo conhecedor da realidade que deveria assumir no Vaticano, o que Pio XII não sabia era o destino da Igreja e da Europa nesse tempo, diante da iminência de um conflito mundial.

Já no início do seu pontificado, Pio XII sabia que seria um período difícil para a diplomacia, em 1939 diante dos acontecimentos e com a crise entre Alemanha e Polônia, a Santa Sé tentou mediar uma conferência de paz convidando as potências europeias, mas essa atitude não teve êxito por falta de apoio.

A reprovação ao comunismo foi uma política constante na diplomacia da Santa Sé, sobretudo, nos pontificados de Pio XI e Pio XII. Por esse motivo, Hitler e Mussolini viam na representação diplomática da Igreja Católica um fator tranquilizador que lhes assegurava apoio (CARLETTI, 2012). Em agosto de 1939, Pio XII dirigiu uma mensagem pela rádio Vaticana para todo o mundo. Foi sua última tentativa diplomática, antes do conflito mundial: “O perigo é iminente, mas ainda tem tempo. Nada se perde com a paz. Tudo pode ser perdido com a guerra. Que os homens voltem a compreender-se. Recomecem as negociações". 6

Ao iniciar de fato a Segunda Guerra, Pio XII tentou convencer a Itália a não entrar no conflito, mas sem êxito, recorda Repgen (1995). As atitudes de Pacelli repetiram a posição de Bento XV, durante a Primeira Guerra Mundial, o fator diferenciador foi a escolha do termo, definidor de suas posições: Pio XII

6 PIO XII. Mensagem Radiofônica "Un'ora grave" aos governantes e aos povos no iminente perigo da guerra. 24 de agosto de 1939. Disponível em: http://w2.vatican.va/content/pius-xii/pt/speeches/1939/documents/hf_pxii_spe_19390824_ora-grave.html>. Acesso em: 02 de junho, 2016. 
preferiu usar a palavra "imparcialidade" ao invés de "neutralidade". Para a interpretação do ex-Núncio da Alemanha a palavra neutralidade tinha um sentido de indiferença passiva, o que o termo imparcialidade não expressava, por se tratar de um "julgamento das coisas segundo a verdade e a legalidade" (CARLETTI, 2012).

\section{ESTRATÉGIAS POLÍTICAS DA SANTA SÉ DURANTE A II GUERRA MUNDIAL}

Quando o termo estratégia é usado para se referir à política internacional, não há uma percepção que fuja da relação com assuntos ligados a guerra. Estratégia é uma palavra grega que tem origem da palavra "stratos", que significa exército, com a palavra "agein", que significa agir. Desta forma a construção do termo estratégia está diretamente ligada à forma de agir de um exército na origem de sua construção.

Já a palavra grega "estrategos" (general) significou em toda a Antiguidade a "arte do general". Bethlem (1981) afirma que palavra general significa "geral", ilustrando o fato de que em algum ponto da história militar o comandante da ação passou a se afastar da linha de frente para poder ter uma visão de conjunto das batalhas, em vez de se envolver diretamente na ação e ter sua visão reduzida a pequeno campo. Teria sido então criada a diferença entre a tática, "arte de conduzir o combate", e grande tática, "arte de preparar e conduzir os exércitos para a batalha".

O que diferencia a estratégia, é pois esta ideia de planejamento e ação a longo ou médio prazo, utilizando meios disponíveis para obter determinados fins e atuando segundo um certo número de regras e princípios. Do campo puramente militar o conceito naturalmente extravasou para os outros domínios. Pode ser útil considerar também um conceito menos lato, o de 
estratégia internacional dum país, tendo em conta não todos os objetivos que esse país se propõe, mas apenas aqueles que dizem respeito à inserção do Estado na vida internacional. (GOMES,1990, p.55)

Ao analisar as estratégias político-diplomáticas usadas pela Santa Sé diante do cenário mundial que se desenhava no período de 1939 a 1945 destacase a figura do Cardeal Pacelli, devido suas posições como autoridade política e espiritual da Igreja Católica, comandante de um exército em “ordem de batalha" em prol da perpetuação do credo católico em plena Segunda Guerra Mundial, bem como devido ao uso de instrumentos diplomáticos como recursos para a consolidação da política vaticana.

Assim, segundo De Sousa (2005) pode-se afirmar que quando se define estratégia nas relações internacionais estamos nos referindo a arte de empregar meios de coação em ambiente hostil. Como ela pode ser praticada pelos mais elevados escalões de decisão, para aquisição de objetivos políticos e de disputas entre unidades políticas, neste caso estaremos nos referindo às tomadas de decisão do líder máximo da Igreja católica, o Papa.

Assim, ao voltar o estudo às ações da Santa Sé, define-se que toda e qualquer decisão é feita por interesses sejam eles políticos ou religiosos e configuram-se como uma estratégia para manter-se atuante no contexto da época. Quando o cardeal Pacelli foi eleito Papa a sua eleição agradou a Igreja da Alemanha que vivendo um momento de apreensão via subir ao trono de Pedro um cardeal que conhecia a realidade do clero germânico, além de ser conhecedor da política internacional. Era religioso, intelectual e de muitas atuações diplomáticas tendo contato com muitos chefes de estado e em especial com o presidente dos Estados Unidos, Rooselvelt em uma época que tal contato se revelava valioso para as relações políticas.

No que se refere a Pio XII, segundo Tomé (2013) ele possuía algumas 
queixas em relação a Adolf Hitler desde a Secretaria de Estado. Pacelli via em Hitler a sua posição anticlerical e sabia que pelos seus interesses ultrapassaria todas as barreiras necessárias para atingi-los. Já em relação ao fascismo a posição do pontífice foi mais branda por uma relativa facilidade para o diálogo com Mussolini do que com Hitler, até quando a Itália decidiu entrar na guerra ao lado da Alemanha quando a austeridade dominou as relações internacionais.

Em agosto de 1939 o mundo vivia a tensão do conflito iminente e as informações começaram a circular de que a Alemanha estava se preparando para invadir a Polônia. De acordo com Pierre Blet (2013, p. 128) em uma audiência com o Secretário de Estado do Vaticano, o embaixador da Polônia revelou que, para a Alemanha “(...) a questão de Dantzig era um pretexto para atacar a Polônia, por forma a chegar à Ucrânia e aos poços de petróleo da Romênia, mas a Polônia esperava calmamente, na certeza de ser defendida pelas potências ocidentais". Nesse cenário, e durante esse período, Pio XII tentou, por meio de mensagens radiofônicas, incentivar as tratativas diplomáticas, o que não sortiram nenhum efeito

O presidente norte-americano também tentou de maneira mais direta buscar a conciliação, e enviou uma longa mensagem para Hitler e Mussolini fazendo-lhes notar que os povos viviam na angústia da agressão, e convidavaos a comprometerem-se, por um período de 10 anos, a não atacar nenhum dos 31 países que ele indicava numa lista. Nesse intervalo, as reivindicações de uns e outros poderiam ser discutidas e resolvidas pacificamente. Roosevelt pediu também a Pio XII para intervir junto de Hitler e Mussolini para reforçar a sua mensagem de 14 de abril de 1940 (BLET,1997, p.20). Diante da rejeição dos clamores diplomáticos de Pio XII pela resolução pacífica do conflito, de acordo com Tomé (2013), o Papa iniciou uma campanha de cartas e mensagens aos seus núncios apostólicos e delegados apostólicos que se encontravam nos países em desacordo. 
Ao iniciar a Segunda Guerra, em setembro de 1939, com a invasão alemã na Polônia, ao analisar a situação que se desenhou na Europa e a realidade que a Igreja Católica teria que enfrentar em todos os seus âmbitos, a Santa Sé se deparava com tal conjuntura:

Os pontos que mais afligiam a Santa Sé por esta altura não se resumiam à situação da Igreja Católica na Alemanha, que desde há algum tempo tinha vindo a sofrer supressões e a ser perseguida. Para além desta questão, a Polônia também preocupava a Santa Sé. A muito católica Polônia, estava agora sob a alçada do Terceiro Reich e a situação da Igreja Católica e seus fiéis mostrava-se bastante complicada, suspeitando-se que os católicos deste país viessem a sofrer represálias semelhantes às dos católicos alemães. As questões raciais e as consequentes perseguições surgiam como outro problema que devia ser combatido e impunha-se tentar salvar o maior número possível de pessoas perseguidas sob pretexto rácico. Por fim, a situação de aliada da Itália colocava o Vaticano em risco: a Santa Sé temia que Roma se tornasse num alvo potencial de bombardeamentos no caso de Itália entrar prontamente no conflito. Era assim importante garantir a neutralidade de Itália, algo pelo qual a Santa Sé se bateu com insistência (TOMÉ, 2013).

Pio XII tentou convencer o governo italiano a não entrar no conflito, mas sem êxito, recorda Repgen (1995). Lebec(1999) afirma que diante da expansão do nacional-socialismo na Europa, as primeiras tentativas de Pio XII foram de combatê-lo mas, por pedido de diversos cardeais, principalmente dos poloneses, o papa optou por agir de forma indireta e buscou proteger a Igreja Católica como instituição, assim como os católicos, principalmente, os das zonas de guerra e, também, manter o Vaticano como um reduto de judeus refugiados.

Na primeira Encíclica de Pio XII, a Sumi Pontificatus - sobre a unidade do corpo social divulgada em 20 de outubro de 1939 o Papa expunha seu programa do pontificado em que subdividia o texto em pontos para ele importantes. De acordo com o resumo publicado do próprio texto continha nos escritos constatações dolorosas sobre o afastamento da fé, afirmava o desejo de ser um 
bom pastor para todos dando testemunho da verdade. Ainda, refere-se aos frutos amargos e movimentos anticristãos, sobre o terrível desastre da guerra, o esquecimento da solidariedade, da origem comum, da fraternidade universal com danos graves para a convivência dos povos, negação da dependência do direito humano do divino. Adverte aos leitores que o Estado não possui autoridade ilimitada; deve fazer tudo convergir para o bem comum; homem e família são anteriores ao Estado. A defesa firme dos direitos da família, o respeito ao direito internacional e aos direitos das gentes como pressuposto da convivência pacífica, a nova ordem internacional que não podia ser estabelecida com as armas, e sim fundar-se sobre o direito natural e revelado, sobre a justiça e a caridade. Outro tema que trata diz respeito a colaboração dos leigos com os sacerdotes no apostolado. Com relação ao Evangelho ajuíza que a Igreja reivindica para si liberdade de ação no anúncio do evangelho. Adverte que a doutrina da Igreja é fundamento seguro para o homem e a sociedade. A hora das trevas, o início de eventos trágicos, a guerra na Polônia. Finaliza o documento fazendo um chamamento à oração para obter o fim das tribulações e uma era nova.

Foi no primeiro texto oficial publicado por Pio XII que o pontífice delimitou posições importantes de sua ação política e pastoral. Já no inicio o Papa expressa:

Enquanto escrevemos estas linhas, veneráveis irmãos, cheganos a apavorante notícia que se desencadeara o terrível tufão da guerra, não obstante todos os nossos esforços para esconjurá-lo. A nossa caneta como que hesita em prosseguir, quando imaginamos o abismo de sofrimentos de inúmeras pessoas, às quais sorria ainda ontem, no ambiente doméstico, um raio de modesto bem-estar. O nosso coração enche-se de angústia, ao prevermos tudo o que poderá medrar da tenebrosa semente da violência e do ódio, depositada hoje nesses sulcos sanguinosos que a espada acaba de abrir.

O conhecimento da realidade internacional e o temor pelo que poderia 
acontecer estavam presentes em seu primeiro texto como pontífice, Pio XII desde o primeiro momento frisou seu interesse pela paz, escolhendo seu lema pontifício: Opus Justitiae Pax- Oportunidade e Paz.

Nesse sentido Pio XII criticava o não cumprimento das concordatas principalmente com o governo alemão e italiano em que as tratativas foram desrespeitadas, a Igreja não recebeu o apoio e abertura que esperava e os pactos foram encerrados de forma unilaterais. Por fazer críticas amenas, e por vezes generalistas no contexto da guerra, a Igreja é acusada de manter o silêncio diante das investidas nazistas, principalmente quanto à neutralidade em relação à invasão da Polônia, tanto que Deschner(1994) afirma que a posição anticomunista da Santa Sé estava disposta a sacrificar a católica Polônia como forma do exército nazista reprimir o comunismo que se estendia sobre o território polonês. Também, diante da invasão da França e de outros países neutros a atuação católica foi de enviar mensagens aos embaixadores junto a Santa Sé e publicar tais escritos nos jornais do Vaticano, porém o Papa não condenou explicitamente as investidas nazistas.

Muitas vezes Pio XII foi acusado de não ter uma palavra mais direta e de não condenar explicitamente a guerra e as investidas de Hitler sob outras nações. Esta questão foi também diversas vezes levantada por alguns representantes junto da Santa Sé. O Papa deparou-se em um contexto de ambiguidade em que necessitava tomar uma posição, mas existia o temor de que sua posição esclarecida prejudicasse ainda mais a situação. $\mathrm{O}$ instrumento do pontífice era apoiar-se em sua rede diplomática e clamando o esforço mundial pela paz, como solução primeira para o conflito que iniciava. Ao traçar uma escala, o Papa via em Hitler um inimigo maior que Mussolini o que causou simpatia para com o regime fascista. Ao encontrar-se no intermédio das potências e na posição de um intercessor falido, a tentativa vaticana de deter a Alemanha vingativa não teve êxito. 
Muitos embaixadores fizeram por vezes pressão para que Pio XII ousasse condenar os regimes totalitários, mas, na fase em que tal tomada de posição poderia talvez ter sido decisiva para evitar a expansão da Alemanha, Pio XII não pronunciou a desejada declaração de condenação. Talvez Pio XII temesse uma resposta da parte dos regimes que pusesse em perigo a sua credibilidade, ao imiscuir-se na esfera política, mas ao mesmo tempo receasse que o regime alemão e italiano lançassem alguma represália, não apenas contra os católicos destes países, mas também contra os católicos dos países que a Alemanha acabara de ocupar. (TOMÉ, 2013, p 96)

Pierre Blet (1997, p.35), aponta uma carta do ministro da Grã-Bretanha Sir d'Arcay Osborne para o Secretário de Estado do Vaticano, Cardeal Maglione como incentivo e apoio aos esforços que a Santa Sé estava travando em favor da paz:

$\mathrm{Na}$ última conversa que tive consigo, perguntou-me se eu acreditava que a Santa Sé tinha feito tudo o que lhe era possível para salvar a paz. Respondi sem hesitação que estava convencido de que sim. Referi essa conversa a Lord Hallifax, que me encarregou de dizer a Vossa Eminência que está inteiramente de acordo com aquilo que lhe respondi.

Segundo Rendina (1993, p. 652) pelo fato de não poder influenciar de forma efetiva o desenrolar do conflito a ação de Pio XII na maioria das vezes passava despercebida como o apoio aos "canais" criados em favor dos refugiados da guerra, o que abordaremos a seguir. Um grande número de pessoas, dentre eles muitos judeus, encontraram refúgio no Vaticano onde encenavam serem membros da Cúria, Pio XII também usou de seus contatos e alianças desde suas viagens com os Estados Unidos para que muitos fugitivos da Guerra pudessem cruzar o Atlântico em busca de paz (THOMAS, 2013). Em regiões da Palestina e na Hungria, bispos e cardeais foram figuras importantes na proteção dos judeus auxiliando na fuga de muitos deles. Assim como sacerdotes se envolveram nos assuntos referentes a Segunda Guerra Mundial na Europa na tentativa de dar refúgio aos perseguidos pelo nazistas, também 
houve eclesiásticos que apoiaram o partido alemão, na própria Alemanha, Croácia e em outros países (DESCHNER,1995) .

Em pouco tempo de pontificado, Pio XII entendeu que para manter-se no cenário mundial era necessário o máximo de cautela, por isso a posição do papa condenava os atos sem condenar os autores. Como afirma Carletti (2012) "A antiga e experiente diplomacia de cunho realista da Santa Sé também ensinara a Pio XII que era importante manter-se por quanto possível acima das disputas para poder conservar margem de manobra política suficiente em caso de mudança do jogo político internacional".

No natal de 1942, Pio XII proferiu um discurso retransmitido pela radio Vaticana que, para muitos, era condenatório à realidade vivida na Europa. Com palavras incisivas afirmou:

Esta guerra mundial e tudo quanto se relaciona com ela, sejam os precedentes remotos ou próximos, ou seus procedimentos e efeitos materiais, jurídicos e morais, que outra coisa representa senão o esfacelo, inesperado talvez para os incautos, mas previsto e deplorado pelos que penetravam com o seu olhar até ao fundo de uma ordem social que debaixo do enganoso rosto ou máscara de fórmulas convencionais escondia a sua fatal debilidade e o seu desenfreado instinto de lucro e poderio? $\mathrm{O}$ que em tempos de paz jazia comprimido explodiu, ao romper da guerra, numa triste série de atos em oposição com o espírito humano e cristão. (...) Este voto deve-o a humanidade aos inumeráveis mortos que jazem nos campos de batalha: o sacrifício da sua vida no cumprimento do seu dever e o holocausto a favor duma nova e melhor ordem social.Este voto deve-o a humanidade à infinda e dolorosa fila de mães, viúvas e órfãos que viram arrancar-lhes a luz, a consolação e o sustento da sua vida. Este voto deve-o a humanidade aos inumeráveis desterrados que o furacão desta guerra desarraigou da pátria e dispersou por terras estranhas. Este voto deve-o a humanidade às centenas de milhares de pessoas que sem culpa nenhuma da sua parte, às vezes só por motivos de nacionalidade ou raça, se vêem destinadas à morte ou a um extermínio progressivo. 
Essa mensagem foi uma das expressões mais críticas de Pio XII em que falou das várias faces do conflito, do racismo, das destruições e das migrações forçadas. Algo que marca seu pronunciamento é não citar: nazismo, perseguições, judeus, antissemitismo. Tal atitude abria brecha para as acusações de silêncio e abstenção de Pio XII, para Grigulevich (1982), a opção por esse posicionamento do papa se devia a preocupação com os fiéis e prelados que se encontravam nas zonas de conflito. Segundo Gordon Thomas (2003), a força tarefa montada pela Santa Sé para esconder os judeus foi de grande magnitude. De outro lado, mesmo com o silêncio, ou por não enfrentar seus inimigos de forma direta, não impediu que muitos sacerdotes e religiosas católicas fossem levados para os campos de concentração. Diante da realidade que se apresentava a ação de Pio XII tinha um significado e estava nos planos estratégicos da geopolítica vaticana, o que expressava uma diplomacia realista, agir de forma calculada e aproveitando as oportunidades para alcançar o êxito mais próximo aos objetivos desejados.

O pontificado de Pio XI, no período entre guerras, buscou estabelecer uma base e uma forma de governar que Pio XII procurou seguir de forma mais flexível e com posições mais amenas o que gerou na história interrogações em relação ao apoio que a Santa Sé teria dado ao nazismo.

O ápice do conflito entre a Alemanha e Santa Sé foi quando Hitler invadiu a Itália, em 1943. O período de ocupação nazista na Itália foi de tensão para o Vaticano que vivia sob pressão de ser invadido por Hitler e ter seus cardeais e bispos, assim como, o papa deportados para os campos de concentração (CARLETTI, 2012, p.117).

No natal de 1943, Pio XII, em seu discurso por meio das ondas de rádio do Vaticano expressou suas opiniões políticas, reafirmando suas posições com palavras incisivas, e com certa impressão de denúncia. Introduziu a mensagem: 
Desgraçadamente o mundo, olhando em redor, deve ainda contemplar com espanto uma realidade de luta a ruína que, tornando-se cada dia mais extensa e cruel, quebranta as suas esperanças e, com glacial e dura experiência, oprime a sufoca os mais ardentes impulsos. Que vemos, realmente, senão que a contenda degenera naquela forma de guerra que exclui qualquer restrição a consideração, como se fosse um produto apocalíptico engendrado por uma civilização em que o Progresso sempre crescente da técnica é acompanhado de míngua cada vez mais profunda de espírito a moralidade; uma forma de guerra que avança sem se deter pelo seu horroroso caminho, a consuma tais estragos que, comparadas com ela, empalidecem as mais ensangüentadas a espantosas páginas das épocas passadas? Os povos tiveram de assistir com terror a um novo a imenso aperfeiçoamento de meios e modos de destruição, a de ser ao mesmo tempo espectadores de uma decadência interior que, desde o resfriamento e o desvio da sensibilidade moral, se vai precipitando cada vez mais para o abismo da sufocação de todo o sentimento de humanidade a do ofuscamento da razão a do espírito, que tornam realidade as palavras de Sabedoria: "todos ficavam presos por uma mesma cadeia de trevas" (Sab 17, 17).

As mensagens de Natal foram as principais oportunidades que Pio XII usou para falar aos católicos e ao mundo no que abrangia ao social e político. No ano de 1943, com o conflito esclarecidamente em seu ápice, as perseguições aos judeus e a invasão nazista em Roma nada mais cabia a Pio XII senão, manifestar seu descontentamento frente à realidade impressa. Com a chegada das forças americanas em Roma e o fim do conflito, Pio XII foi saudado pelos romanos que exaltavam a personalidade do pontífice e afirmavam ter sido a única autoridade moral e religiosa que se manteve ao lado do povo nos tempos mais cruéis (CARLETTI, 2012,p. 119). No Natal de 1944, o Papa Pio XII fez uso de sua tradicional mensagem para defender a democracia, e apoiar a organização de uma comissão internacional que possibilitasse a segurança internacional a fim de definir leis internacionais de respeito aos direitos humanos e o progresso social, o que mais tarde se constituiria na criação da ONU. Também usou de seu discurso para esclarecer e diferenciar os termo povo e massa, fazendo uma alusão direta à ideologia comunista: 
Povo e multidão amorfa ou, como se costuma dizer, "massa", são dois conceitos diversos. O povo vive e move-se por vida própria; a massa é de si inerte, e não pode mover-se senão por um agente externo. $\mathrm{O}$ povo vive da plenitude da vida dos homens que o compõem, cada um dos quais - no próprio lugar e do próprio modo - é uma pessoa consciente das próprias responsabilidades e das próprias convicções. A massa, pelo contrário, espera uma influência externa, brinquedo fácil nas mãos de quem quer que jogue com seus instintos ou impressões, pronta a seguir, vez por vez, hoje esta, amanhã aquela brincadeira. (...) Daí desponta clara outra conclusão: a massa qual acabamos de definir - é a principal inimiga da verdadeira democracia, e do seu ideal de liberdade e de igualdade.

Diante destas declarações no pós-guerra, Pio XII impôs, de forma clara, a condenação ao comunismo, o que para a Igreja era um compromisso, uma questão a ser combatida. Diferentemente de toda a cautela usada na oposição ao nazismo e aos acontecimentos da Segunda Guerra. Durante a Guerra Fria, de 1945 até sua morte, o pontífice esclareceu sua posição e formalizou princípios e valores defendidos pela diplomacia Vaticana, apontando abertamente o inimigo da Igreja Católica e das famílias cristãs.

Analisando-se as posições tomadas pela Santa Sé e as atitudes apoiadas por Pio XII, que demonstra a necessidade de olhar para a realidade que se estabeleceu, e que Koselleck (2006) chama de expectativa apocalíptica. É no cenário da Segunda Guerra Mundial e no governo de um Estado que se comporta com princípios diferentes dos da maioria dos Estados que se pode ver a estrutura da expectativa conceituada pelo autor, onde mesmo com experiências negativas ou contrárias não abalam a certeza do que não é alcançável de forma natural e ainda reafirma a esperança do porvir.

Ao encerrar a Guerra Pio XII, alertou para as consequências políticas e ideológicas em que as situações poderiam se transformar. O perigo totalitário da União Soviética e os castigos que o mundo tentaria impor sobre a Alemanha. Com medo do crescimento do comunismo na Europa e como o 
cenário da Guerra Fria que se revelou, Pio XII iniciou uma força tarefa para apoiar na Itália os grupos políticos que lutaram contra os fascistas. Para Carletti (2012), o fortalecimento desses grupos católicos era a possibilidade de barrar as forças esquerdistas que ameaçavam voltar a influências o mundo ocidental. Encontrando-se no coração da Itália, a Santa Sé influenciava a configuração política da península fortalecendo os grupos católicos e ao sair das incertezas da guerra, as organizações partidárias mostravam-se instrumentos de estabilidade e presença da Santa Sé.

\section{CONSIDERAÇÕES FINAIS}

Consideramos que a Santa Sé é um ator internacional que merece uma análise específica por abarcar características diferentes dos outros Estados e por interferir em posições, comportamentos e vida de indivíduos de diversas nacionalidades mas que têm na figura do Papa como líder político e religioso um formador de opinião. Desta maneira além de do estudo da religião ser importante na composições e desenvolvimento da nova história política que atua como destaque na análise da história das relações internacionais, a Santa Sé é enquadrada como protagonista em diversos acontecimentos na história da humanidade.

A estratégia política como uma arte e uma ciência descritiva, como afirma Sousa(2005), pois é planejada sistematicamente a partir do perfil do que pretende-se combater, para tanto é importante a, formulação de hipóteses, e nesta caso em estudo, elaboração de teorias, leis, princípios e conceitos capazes de dissuadir o oponente. Enquanto prática, o estrategista usa a liberdade de ação, aleatoriamente, ou seja, dependendo das circunstâncias usa a seu favor, de acordo com seus interesses, seja no campo político ou religioso. Ao tomar esse 
fator como imprescindível ao fator interno na construção de uma política de estado, sem deixar as características religiosas de seus atores diplomáticos, é possível vislumbrar que a Santa Sé, seguindo a filosofia de seu líder de Estado, buscou uma diplomacia onde a negociação e também a invisibilidade fossem peças chaves em suas decisões.

Buscando a interpretação das ações do Vaticano, mais especificamente no pontificado de Pio XII, e analisando as motivações para o comportamento da diplomacia vaticana percebe-se a tentativa do pontífice de formar uma estratégia política que abarcasse os valores, não só de um ator internacional, o Estado do Vaticano, mas também da instituição Igreja Católica.

O Pontificado do Papa Pio XII teve muitas críticas posteriores em que foi acusado de fazer conivência com os nazistas calando-se diante das atrocidades e destruições do regime. Alguns autores justificam esses argumentos dizendo que Pio XII nunca atacou os nazistas diretamente, nomeando Hitler e o regime alemão. De outro lado a partir dos discursos demonstrados nos textos vê-se uma linha de diplomacia em que o Papa fala sobre o assunto, posiciona-se, porém não nomeia os atores de forma direta. Os comportamentos de Pio XII representam a maior parte da expressão da política exterior da Santa Sé, demonstrando cautela mas em certa medida sendo consciente da postura que deve tomar no cenário internacional.

No cenário mundial o Vaticano se projetou com estratégias de um verdadeiro estado-nação ao usar das ferramentas de soft power, pois com suas estratégias políticas manteve-se atuante na ordem internacional durante a Segunda Guerra Mundial. Compreender qual a postura assumida pela Santa Sé e qual o seu papel no cenário internacional fez-se de extrema importância, dessa forma não há intenção de supervalorizá-la politicamente, mas reconhecer que 
detém uma figura de influência dependendo dos momentos e relevância dos fatos.

Ao estudar os comportamentos e acontecimentos de um período de conflito mundial e a observação de um Estado Nação, em particular a Santa Sé, pretendeu-se responder a pergunta onde o silêncio e ação são a própria resposta, pois nas relações internacionais considera-se o silêncio, a imparcialidade e a cautela como tomada de decisões estrategicamente pensadas onde a forma de defender o status quo do país e seus interesses são combinadas.

\section{REFERÊNCIAS}

BEHLEM, Agrícola. Os conceitos de política Estratégica.1981 Disponível em: http:/ / www.scielo.br/scielo.php?script=sci_arttext\&pid=S003475901981000100001. Acesso em: 22 mai 2017

BLET, Pierre. Pio XII y la Segunda Guerra Mundial a partir de los archivos del Vaticano ,Paris: Perrin, 1997.

CARLETTI, Ana. O internacionalismo vaticano e a nova ordem mundial. Brasília : [s. n.], 2012.

DE SOUSA, Fernando. Dicionário de Relações Internacionais. Porto: CEPESECentro de Estudos da População, Economia e Sociedade, 2005.

DE SOUZA, Salmo. A Santa Sé e o Estado da Cidade do Vaticano: distinção e Complementaridade. Revista da Faculdade de Direito da Universidade de São Paiulo. V. 100, 2005. Disponível em: < http://www.revistas.usp.br/rfdusp/article/view/67675> Acesso em: 25 de agosto de 2017.

DOSSE, François. A História em Migalhas: dos Annales à Nova História. Bauru: EDUSC, 2002

DESCHNER, Karlheinz. La Política de los Papas em el siglo XX. Com Dios y com los fascistas (1939-1995). Volumen II. Zaragoza:Yalde, 1995. 
GODMAN, Peter. O Vaticano e Hitler. São Paulo: Martins Fontes, 2007.

GOMES, Gonçalo S.C.A Política Externa e a diplomacia numa estratégia nacional. 1990. Disponível em:< http:/ / comum.rcaap.pt/handle/10400.26/2669> Acesso em: 22 de agosto de 2017

GRIGULÉVICH, Iosif. El papado, siglo XX. Moscú: Editora Progreso, 1982.

KOSELLECK, Reinhartet. Futuro Passado: contibuição à semântica dos tempos históricos. Rio de Janeiro: Contraponto: Ed. PUC-Rio, 2006.

LEBEC, Eric. História Secreta da Diplomacia Vaticana. Petrópolis: Editora Vozes, 1999.

MARTINS, Estevão. História das Relações Internacionais. In: CARDOSO, Ciro (Org.). Novos Dominios da História. Rio de Janeiro: Elsevier,2011.

MONTENEGRO, Enrique. et. al. Tendencias Historiográficas Actuales: Historia Medieval, Moderna y Contemporânea. Madrid : Editorial Universitaria Ramón Areces, 2013

MOREIRA, Adriano. Teoria das relações internacionais. Coimbra: Livraria Almedina, 1996.

NYE, Joseph. Cooperação e Conflito nas Relações Internacionais. São Paulo: Editora Gente, 2009.

PIO XII. Mensagem Radiofônica: “Un'ora grave” aos governantes e aos povos no iminente perigo da guerra. 24 de agosto de 1939. Disponível em: http:/ / w2.vatican.va/content/pius-xii/pt/speeches/1939/documents/hf_pxii_spe_19390824_ora-grave.html>. Acesso em: 02 de maio de2017.

. Carta Encíclica: Summi Pontificatus. 20 de outubro de 1939 Disponível: < https://w2.vatican.va/content/pius-xii/pt/encyclicals/documents/hf_pxii_enc_20101939_summi-pontificatus.html> Acesso em: 02 de maio de 2017.

. Mensagem Radiofônica: Con Sempre Nuova Freschezza. 24 de dezembro de 1942. Disponível em: < https://w2.vatican.va/content/piusxii/pt/speeches/1942/documents/hf_p-xii_spe_19421224_radiomessagechristmas.html> Acesso em: 13 de maio de 2017.

PORTILHO, Ana Claudia. O ator Santa Sé na Política Internacional moderna. 2011. Disponível em:

<http:/ / www.proceedings.scielo.br/scielo.php?pid=MSC0000000122011000100 013\&script=sci_arttext $>$ Acesso em:12 jun 2016. 
REIS, Bruno. A política externa do Vaticano de Bento XVI, 2007 . Disponível em: http:// janusonline.pt/2007/2007_4_3_9.html. Acesso em: 14 mai 2017

RÉMOND, René. Por que a história politica? Revista Estudos Históricos. Rio de Janeiro, volume 7, número 13, p. 7-19.1994.

REPGEN, Konrad. La política estera dei papi nel período delle guerre mondiali. MILÃO: Jaca Book, 1995.

TOMÉ, Romina. A Diplomacia da Santa Sé: evolução e questões atuais. 2013, Dissertação Mestrado em Universidade de Évora, Évora, 2013.

TORNIELLI, Andrea. Pio XII- O Papa dos Judeus. Rio de Janeiro: Civilização Brasileira, 2002. 